\title{
Post-neoliberal housing policy? Disentangling recent reforms in New York, Berlin, and Vienna ${ }^{1}$
}

\begin{abstract}
In cities worldwide, the housing question has returned. As demands and proposals by housing movements have grown bolder, city governments are implementing new policies, ranging from small tweaks to major overhauls. This paper takes a close look at New York City, Berlin, and Vienna, assessing their current housing policy landscapes. We evaluate to what extent those cities' recent housing reforms depart from the dominant, neoliberal policy landscape of recent decades and can be categorized as "post-neoliberal". We do so through the criteria of affordability, decommodification, and democratisation. The three selected cities display varying histories of housing systems and neoliberalisation, enabling us to search for post-neoliberal policies in three distinct institutional contexts. We find a common pattern across cases: recent reforms have improved affordability and dampened hyper-commodification, but little has been done to address the democratisation of housing and planning systems. By way of conclusion, we discuss some of the structural factors that impede attempts at developing a genuinely post-neoliberal transformation of local housing policies.
\end{abstract}

Keywords: post-neoliberalism, housing policy, policy analysis, New York, Berlin, Vienna

Justin Kadi, TU Wien

Lisa Vollmer, Bauhaus-Universität Weimar

Sam Stein, City University New York

Introduction

The housing question is back: all over the world, tenants are fighting for institutions and policies that can deliver affordable and decent housing for all. They do so by proposing concrete alternatives to prevailing neoliberal housing policies, including such demands as expanding public housing, further regulating the private rental sector, and even expropriating financialised housing companies. As movement demands and proposals have grown bolder, how have city governments responded?

This paper takes a close look at three cities, New York City, Berlin, and Vienna, and assesses their current housing policy landscapes, i.e. the institutional structure of the housing market, in order to evaluate the extent to which those cities' recent housing reforms can be characterised as "postneoliberal". Following Schipper (2015) as well as Brand and Sekler (2009: 6), we take post-neoliberalism as an analytical framework to identify policies that strategically break with market-based policy making. We operationalize this general notion with regard to housing in a tripartite heuristic prior to our analysis.

The paper is thereby embedded in a more general debate about the crisis of neoliberalism and neoliberal urbanism (Smith 2008, Belina and Schipper 2009, Streeck 2011, Parnell and Robinson, 2012;

\footnotetext{
${ }^{1}$ This is the accepted version of the manuscript Kadi J, Vollmer L and S Stein (2021) Post-neoliberal housing policy? Disentangling recent reforms in New York, Berlin, and Vienna. European Urban and Regional Studies, online first. (C) The Author(s) 2021 DOI: 10.1177/09697764211003626
} 
Rossi and Vanolo 2015) and the advent of post-neoliberalism (Brand and Sekler, 2009; Peck et al. 2010; Aalbers, 2013; Springer, 2015), and it specifically contributes to a beginning debate around postneoliberal housing policies. This debate mainly revolves around German cities (Schipper 2016, Schipper 2018, Rinn 2018, Sarnow 2019, Schönig et al. 2016, Vogelpohl and Buchholz 2017) and examines to what extent recent local housing reforms depart from established market-based policy trajectories. While authors differ in their assessment, some see a significant post-neoliberal shift; Vogelpohl and Buchholz (2017:266) even speak of a "breaking with neoliberalization" in the case of Hamburg. Others strongly dispute this diagnosis (Rinn 2018).

Although this literature provides relevant empirical insights into, and interpretations of, recent local housing reforms, we see two gaps. First, the debate so far focuses almost exclusively on German cities (but see Schipper, 2016 for an exception). Thus, we do not know to what extent similar developments take place in other institutional contexts facing housing crises. Second, no systematic framework has yet been proposed to evaluate to what extent housing policies can be considered "postneoliberal". Consequently, authors have referred to conflicting, often implicit criteria. We address these gaps in two ways. First, we provide an analysis of policy reforms in three cities with different institutional contexts, including both a North-American and two Western European cities. Second, we propose an analytical framework to assess the reforms' post-neoliberal content. Taken together, these two steps allow us to arrive at statements that are both broader (geographically) and more differentiated (in terms of post-neoliberal content) than much of the existing literature. ${ }^{2}$

The three selected cities share certain commonalities in their housing markets, with a mixture of public or municipally-controlled rentals, subsidized and rent-regulated private rentals, unregulated rentals and owner-occupied units, but their housing systems derive from contrasting political and historical currents. We follow Bourne (1981: 12) in defining a housing system as "the full range of interrelationships between all of the actors (individual or corporate), housing units and institutions involved in the production, consumption and regulation of housing. It is thus a much broader term than housing market or sector". Housing systems are shaped at least as much by path-dependent institutional arrangements, unintended policy outcomes and effects of other policy subsystems as they are by intentional policy formulations.

New York City is situated in the United States' liberal housing system, with government housing provision and rent controls arising out of exceptional moments of crisis, thus creating a residualised segment of public housing for a small segment of the population and a dominant logic of market-based housing provision. Berlin, by contrast, is situated in (West-)Germany's conservative-corporatist housing system (Schönig and Vollmer 2018) that includes private and collective housing providers as well as a significant segment of regulated housing for a broad spectrum of society, yet continues to rely to considerable degree on market housing provision. Vienna is also situated in a conservative-corporatist national housing system, but is characterized by comparably far-reaching state interventions into the market and non-market housing provision which originated in the experiments with municipal socialism of 'Red Vienna' in the 1920s (Matznetter, 2002; Kadi, 2015). While overall the three cities have quite

\footnotetext{
2 This paper builds on an earlier paper on Vienna and Berlin by Vollmer and Kadi (2018) (in German), but significantly extends it by including a more elaborate conceptual framework, more recent developments in the empirical analysis, adding a third case study, New York City, and reflecting on the barriers to further postneoliberal transformation.
} 
distinct local housings systems, New York more strongly leans towards a dualist rental market (cf. Kemeny, 1995; Radford, 1996) in which residualised non-market housing does not compete with forprofit renting, whereas Berlin and Vienna's more unitary systems allow the two to compete more directly (Mundt and Amann, 2010). The discourses about housing and the degree by which people are used to demanding state intervention also vary between the three cities. What unites the cases, meanwhile, is that all three are more interventionist than other cities in their respective countries, although the overall principles of their national housing systems certainly shape local policy landscapes.

The three cities also differ in their degree of neoliberalisation before the recent policy reforms. New York City, the largest of the three cities under review, certainly underwent the deepest neoliberalisation to its housing policies beginning in the mid-1970s and granted a high degree of power and influence to private real estate interests (Moody 2007). Berlin's housing system sits between New York's and Vienna's in this regard. Relative to those cities, however, it has gone through the swiftest and most severe rise in rents (see also Table 1) and has undertaken the boldest set of housing reforms (Vollmer/Kadi 2018). Vienna's neoliberal turn, though significant, was the mildest of the three cities, and the city has continued to pursue policies to curb private market influence (Kadi, 2015).

Any comparison between the three housing markets is complicated by their varying legal contexts, as well as the considerable degree of variation within the three cities. Nonetheless, the general comparison in Table 1 shows how varying histories of housing policies and neo-liberalisation have left their marks on the three markets. New York, as the most liberal market, has the smallest share of municipally-controlled public rental sector ${ }^{3}$ as well as social cooperative/non-profit housing. Berlin ranks between the other two cases in this regard, while Vienna clearly leads. In terms of affordability, New York has the highest rent-to-income burden, followed by Berlin and Vienna. As the rent increase shows, however, all three cities have experienced a rapid escalation in housing costs over the last ten years.

Table 1: Housing markets along stock size, sectors, affordability and rent increases (most recent data available)*

\begin{tabular}{|l|l|l|l|l|l|l|l|}
\hline & $\begin{array}{l}\text { Housing } \\
\text { stock } \\
\text { (units, } \\
\text { rounded } \\
\text { to the } \\
\text { nearest } \\
\text { thousand) } \\
\text { housing } \\
\text { rental } \\
\text { hunicipal }\end{array}$ & $\begin{array}{l}\text { Social } \\
\text { cooperati } \\
\text { ves and } \\
\text { non-profit } \\
\text { housing* } \\
*\end{array}$ & $\begin{array}{l}\text { Private } \\
\text { rental } \\
\text { housing } \\
* * *\end{array}$ & $\begin{array}{l}\text { Owner- } \\
\text { occupied } \\
\text { housing }\end{array}$ & $\begin{array}{l}\text { Percentage } \\
\text { of rent } \\
\text { burdened } \\
\text { tenants } \\
\text { (paying } \\
\text { above 30\% } \\
\text { of income } \\
\text { for contract } \\
\text { rent)**** }\end{array}$ & $\begin{array}{l}\text { Rise in } \\
\text { average } \\
\text { rents over } \\
\text { the last ten } \\
\text { years, } \\
\text { inflation } \\
\text { adjusted }\end{array}$ \\
\hline $\begin{array}{l}\text { New } \\
\text { York }\end{array}$ & $3,470,000$ & $5 \%$ & $9 \%$ & $58 \%$ & $23 \%$ & $48 \%$ & $15 \%$ \\
\hline Berlin $^{2}$ & $1,950,000$ & $15,5 \%$ & $10 \%$ & $59 \%$ & $15,5 \%$ & $40 \%$ & $21 \%$ \\
\hline Vienna $^{3}$ & 905,000 & $23 \%$ & $21 \%$ & $33 \%$ & $19 \%$ & $32 \%$ & $16 \%$ \\
\hline
\end{tabular}

${ }^{1}$ Gaumer (2018); Mironova and Waters, 2020; US Census Bureau, 2009 and 2019.

2 IBB (2020: 44, 50, 81, 70); own calculations based on Statistik Berlin Brandenburg (2020)

${ }^{3}$ Statistik Austria (2019); Rent-burdened households: own calculation based on EU-SILC, 2017

\footnotetext{
${ }^{3}$ Defined as housing owned by the municipality.
} 
* Due to the varying structure of the three markets, only comparable housing sectors are included. Therefore, the sectors do not add up to $100 \%$ in all three cases.

**This includes for New York subsidized rental buildings and Mitchell-Lama and HDFC cooperatives, for Berlin

Genossenschaften, and for Vienna units owned by non-profit housing providers (Gemeinnützige Bauträger).

$* * *$ In all three cities, parts of the private rental market are rent-regulated.

**** For Vienna: total housing costs.

While we acknowledge the important differences in the cases' housing systems, our starting point is that all three cities have undergone marked neo-liberal housing reforms, a related rise in housing hardships and protests, and significant new governmental interventions. For each city, our aim is to assess these recent policy reforms and to evaluate whether they can be characterized as "postneoliberal" (a category we define in the next section). In so doing, we analyze to what extent we can observe a departure from the dominant, neo-liberal policy trajectory across different institutional contexts. We are thus not primarily concerned with a static comparison of housing markets and problems, but with a dynamic comparison of policy trajectories in cities with different housing systems that have recently undergone comparable changes (cf. Hay, 2004). Our focus is on three within-case comparisons of policy developments over time, following our defined criteria of post-neoliberal housing policies.

Though the situation in all three cities is fluid, we address the housing policies and reforms that took place during the second decade of the $21^{\text {th }}$ century (as of March 2020, before the Covid-19 crisis triggered new temporary policy reforms). We find that all three cities have made significant departures from market-based policies, but a coherently post-neoliberal housing policy regime has not yet emerged. Indeed, vital elements of urban neoliberalism persist - and in some cases have deepened. In the conclusion, we discuss some structural factors that stand in the way of a genuinely post-neoliberal transformation. We begin by introducing our analytical framework before turning to our cases.

\section{Operationalizing post-neoliberal housing policy}

In the context of the 2008 global financial crisis, a debate has emerged in the social sciences about the current state of neoliberalism (Peck, Theodore and Brenner, 2010; Aalbers, 2013; Brand, 2016). The main source of contention is over degree of change: are capitalist cities and countries undergoing a structural shift in governance away from market-intensification and commodification, or are they rather undergoing a partial discontinuity of institutional practice within an otherwise - and perhaps even deepening - neo-liberal order (cf. Smith, 2008; Crouch, 2011; Mirowski, 2013)? We have no intention of settling this general debate. Instead, we follow the call by Brenner et al. (2010) to produce detailed empirical research that disentangles the development of regulatory structures in different policy spheres. We do so by using post-neoliberalism as a framework to assess whether recent housing reforms significantly depart from their dominant, market-based policy trajectory in different institutional contexts.

Our definitional starting point is that neoliberalism is a dominant yet contradictory practice of market-based regulatory restructuring that began in the 1970s in different political, economic, social, and cultural contexts and across various geographical scales (cf. Peck, Theodore \& Brenner, 2010). Postneoliberalism provides an analytical lens to search for "different responses to the (negative) impacts of neoliberalism and its growing inability to deal with [these] contradictions" (Brand and Sekler, 2009: 6). It is thus less a term describing current conditions than an analytical heuristic (Schipper, 2015). As 
Macdonald and Ruckert (2009:8) argue, post-neoliberalism is an attempt to grasp "a host of variegated social practices and discourses that strategically engage with contested forms of neoliberal governance".

In the sphere of housing, a number of authors made the case that German cities had departed significantly from neoliberal policy. They employ different notions of what that break entails, what exactly is to be studied, and what the destination of this departure might be. Schipper (2015), for example, builds on a framework by Brenner et al. (2010) to look at developments in three different spheres: regulatory experiments, discursive mechanisms, and 'rule regimes' of neoliberalisation. He gives no clear criteria, however, for what constitutes a shift away from neoliberalisation, besides the rather general goal of constraining the commodity status of housing (Schipper, 2018: 8f). In their comparative study of four German cities, Schönig et al. (2016:26) define post-neoliberal housing policies as a return to the housing policies of the post-war welfare state. Vogelpohl and Buchholz (2017) see "important steps toward the direction of a city for all" taken in Hamburg through „experiments to reduce property-led displacement, to reregulate the market and to strengthen rent-controlled social housing" (2017:14f). None of these contributions, however, develops a comprehensive framework or criteria to evaluate what, exactly, constitutes genuinely post-neoliberal housing policies.

Given that post-neoliberalism constitutes a regulatory departure from neo-liberal policy practices, any operationalisation of post-neoliberalism requires first a clear understanding of what neoliberal practices entailed in different policy spheres. In housing, as in other spheres, market-based policies were highly variegated and differed in concrete form across contexts (e.g. Kadi and Ronald, 2014). However, some general traits can be distinguished. Here, we focus on three:

First, neo-liberal housing policies are characterized by the commodification of housing segments that were not yet organized as private markets. This included, inter alia, the sale, demolition, or disinvestment of social and public rental housing, but also a deepening commodification of already commodified sectors like private rental housing through the weakening of rent regulations, or in some cases their full-fledged liberalisation (Jacobs, 2019; Kadi and Ronald, 2014). Additionally, the financialisation of housing, or the growing importance of actors and logics of the financial market in housing, represents a specific form of commodification (Aalbers 2013) that played out differently in the three cities we consider (Fields and Uffer, 2016; Kadi, 2020), but certainly influenced the housing systems immensely. One component of post-neoliberal housing policy must thus relate to the decommodification of formerly commodified sectors, e.g. through re-municipalisation, the expansion of non-market housing through subsidy programs, new state-led provision or policies and initiatives to regulate and drive away financialized housing actors.

Second, neo-liberal housing policies entailed the reduced affordability of housing for low- and middle-income households (Kadi and Ronald, 2016). While in some cases this occurred as a consequence of hyper-commodification and can thus be rather seen as an effect of neo-liberalisation, in other, more revanchist strategies, the reduction of the affordable housing supply became an intentional policy goal (cf. Smith, 1996; Goetz, 2013). Entrepreneurial urban policies (Harvey, 1989), for example, often included the promotion of gentrification as a form of demographic politics, to displace poorer people and attract the middle- and upper-classes (and their tax revenues). Consequently, a second component 
of post-neoliberal approaches relates to measures to deepen housing affordability, ${ }^{4}$ particularly for lower- and also for middle-income groups through subsidy programs, new social rental housing, or the introduction or tightening of rent regulations.

A third characteristic of market-based restructuring in housing relates to the form of governance and the reshaping of power relations in housing production and planning procedures. Under neoliberalism, real estate and financial capital were given greater influence, while the roles of residents, tenants, and their political representatives were reduced (Harvey, 1989; Stein, 2019). Post-neoliberal housing policy must thus entail greater democratisation in these domains. Democratisation, as used here, refers to the formal inclusion of tenant representatives, civil society movements and working-class organizations in decision-making bodies and processes such as in planning procedures for new housing development, decisions related to new housing policy-making, or decisions related to housing providers' operations and management.

While these three dimensions are to some extent interdependent (e.g. improved affordability often goes hand in hand with decommodification and vice versa), policies may also relate to just one dimension (e.g. improved affordability without democratisation). From an analytical perspective, it is therefore useful to treat the three dimensions distinctly. Given the tripartite form of neoliberal policies, however, for reforms to systematically break with the dominant policy paradigm - and, thus, to be considered genuinely post-neoliberal - shifts in all three domains must take place.

With this brief conceptual framework in place, we now turn to our analyses of local housing reforms. We consider the three housing systems in turn, starting by briefly sketching each city's housing market structure, the role of the municipality in housing policymaking, and the main components of the market-based reforms that predate recent local policy shifts. In the second part of each case study, we describe recent reforms, structured along the following dimensions: housing sectors (municipal/public housing, social cooperative/non-profit housing, and private rental housing); land policy; and governance. The third part of each cases study assesses these reforms with regard to our three criteria of post-neoliberalism: decommodification, affordability, and democratisation.

\section{New York}

New York's neoliberal housing policy landscape

New York City is a mixed-form housing market (Marwell and Mcinerney, 2005), combining forprofit and non-profit models, private and public provision, and market-based and formula-based price setting. Its 3,469,240 total units are roughly divided between owner-occupied homes (31\%, of which $9 \%$ are limited-equity cooperatives), rent regulated private rental housing (30\%), unregulated private rental housing $(28 \%)$, various types of subsidized private rental housing $(5 \%)$, and publicly-owned and managed housing (5\%) (Gaumer, 2018). ${ }^{5}$

\footnotetext{
${ }^{4}$ In public debates, affordability is usually defined as paying less than $30 \%$ of income as rent in New York and Berlin, and less than $25 \%$ of income in Vienna.

${ }^{5}$ This analysis combines data from the 2017 Housing Vacancy Survey (Gaumer, 2018) with the latest unit counts from the New York City Housing Authority and a database of subsidized housing compiled by the Community Service Society of New York.
} 
The city government is involved in several aspects of housing policy, including: setting land use and zoning rules; financing private affordable housing production; controlling the public authority that manages public housing; choosing the members for a board that determines rent increases in rent regulated apartments; and overseeing the provision of shelter beds and social services for homeless people. Local government, however, is restricted from taking more serious action on rent setting, public housing finance, and real estate taxation as a result of deep neoliberal restructurings that took place at the state and federal levels beginning in the mid-1970s.

In 1975 New York City faced a fiscal crisis, and the State government intervened to impose a series of long-lasting austerity measures. During the same time period, public housing was radically defunded at the federal level, with the deepest cuts in the 1980s never restored to their previous levels (Goldstein, 2017: 210). Until very recently, the state's rent control system (operating primarily in New York City) was subject to multiple rounds of retrenchment, which offered landlords abundant opportunities to raise rents and remove units from regulation (Gurian, 2003). Tax policies have been structured to incentivize luxury housing development and conversion, with billions of dollars spent annually on programs that have yielded little in terms of low-income housing (Whitlow, 2019). Zoning has been relied upon over all other planning tools to manage growth, with hundreds of neighbourhoodlevel rezonings following a similar pattern: blocks that are home to high-income, predominantly white homeowners have often been downzoned to preserve their low-density character; blocks that are home to relatively low-income, predominantly African American and immigrant tenants have often been upzoned to incentivize new development, little of which was affordable to the neighbourhood's existing residents (Angotti and Morse 2016). While the city's planning and development regime has, since 1975, been subject to a standardized participatory scheme known as the Uniform Land Use Review Procedure, this system has often operated more as political theatre than a space for deliberative democracy (Carr, 2012).

The result of this neoliberal regime has been that housing in New York has come to be characterized as highly unaffordable, deeply commodified, and undemocratically planned. The city faces a severe and persistent housing emergency, with more than 60,000 people reported homeless (Coalition for the Homeless, 2019). Rents have outpaced wages, placing crushing rent burdens on residents, particularly those at the lower end of the income spectrum. While developers continue to build, with previous construction records broken in 2019, much of the new housing is aimed at upper-market renters and buyers (Braun, 2020). Between 2002 and 2017, rents for recent arrivals went up 47\%, while the number of apartments affordable to low-income households declined $49 \%$. Given these figures, the existence of a housing crisis is universally recognized across the city's political spectrum; however, the nature of the problem - and therefore its causes and solutions - is widely debated, with calls by elected officials and policy advocates for both clearer breaks from neoliberal housing policy and deeper commitments to them.

\section{Housing policy responses}

Resurgent housing activism (Vollmer 2019, 2020), combined with the reformist mayoralty of Bill de Blasio beginning in 2014 and the emergence of a functional Democratic majority in the New York State legislature 2018, have created opportunities for new housing policies to challenge elements of the neoliberal paradigm, particularly in the realm of affordability. Some of the most impactful changes have been in the regulation of rents and evictions in private rental housing. In 2015 and 2016, the mayorly- 
controlled Rent Guidelines Board voted for the first time in its history to freeze rent stabilized rents and has since opted for lower rent increases than was the standard during previous administrations. ${ }^{6}$ In 2017 the City Council passed a long-sought "right to counsel" act that guarantees free legal representation to low-income tenants facing eviction (Whitlow, 2019). In 2019 the New York State legislature passed a major revision to the rent regulations, which significantly strengthened the existing rent control system. While this did not decommodify rent controlled housing, it restricted some of the most predatory speculative behaviours by corporate landlords and investors. As a result of these measures, evictions in New York City have declined, with an especially steep drop (46\%) in the year following the new rent law's passage (Barbanel, 2019).

Affordable housing construction and preservation has also seen significant investment under the de Blasio administration. New affordable housing starts have exceeded all previous mayors during the neoliberal period, with an average of 25,000 units produced per year since 2014 (Schwartz, 2020: 363), though housing organizers and advocates charge that production still lags demand, particularly for the lowest-income New Yorkers. Public housing has also been given new attention by city policymakers. Recent controversies have highlighted the need for intensive reinvestment in public housing, with many developments in a persistent state of disrepair due to deferred maintenance, climate change, and a scandalous lead paint coverup. Federal funding levels remain inadequate, and long-promised State budgetary assistance is only now beginning to manifest (DiPrinzio, 2019). In light of these shortfalls, the de Blasio administration's two primary strategies for generating funds have been to incentivize the production of new private housing on public housing grounds and to shift a majority of public housing developments into private management through the federal Rental Assistance Demonstration (RAD) program. Paradoxically, this strategy aims to commodify public land and housing in order to preserve public housing. Public opinion on these policies has been mixed: while some residents and advocates celebrated these policies for promising desperately needed funds, others criticized them as moves toward privatisation that could ultimately increase precarity.

To incentivize new private housing development, the de Blasio administration pursued a Mandatory Inclusionary Housing policy that mandates the inclusion of income-targeted housing in any new residential development built as a result of an upzoning (Newman, 2018). The administration pitched this as a way of democratizing the outcome, if not the process, of planning for new development. Following this citywide legislation, city-sponsored neighbourhood upzonings were passed in six areas, and 73 individual parcels were upzoned at developers' request. While some non-profit developers supported the mayor's plan, many tenant organisations opposed it, arguing that the effects of the new affordable housing production would pale in comparison to the inflationary impacts of increased market-rate development in neighbourhoods vulnerable to gentrification. All of the approved neighbourhood upzonings have been located in working class and majority Black, Latino, or Asian neighbourhoods, but the kind of affordable housing the rezonings would produce is unaffordable to most New Yorkers of colour (Stein, 2018).

This zoning disparity highlights the persistently ad-hock and inequitable aspects of the city's planning repertoire, which has not been subject to the same degree of reform as the rent regulation systems. Which neighbourhoods are subject to rezoning proposals is largely determined by a

\footnotetext{
${ }^{6}$ Another 1-year rent freeze was passed in 2020, though emergency policies passed during the Covid-19 pandemic are beyond the scope of this analysis.
} 
combination of mayoral and developer power; which rezonings are completed is largely determined by individual City Councilmembers. The result of this dynamic is a system that imposes the costs of growth on the most vulnerable populations while shielding wealthier enclaves from intensive redevelopment. Grassroots mobilisations, however, have frustrated some of these plans. A combination of tenant and union power scuttled the city and state's plans to subsidize Amazon's proposed new headquarters, and community opposition and legal action have stopped rezonings in several working-class neighbourhoods.

\section{Post-neoliberal New York?}

Undeniably, a change has occurred in New York City housing policy: new regulations are protecting more tenants from evictions and extreme rent increases, and new developments are being offered to lower-income residents. It is not clear, however, that these changes constitute a postneoliberal paradigm shift in the city's housing policy regime. First, changes that protect tenants have been accompanied by plans that disproportionately benefit real estate capital, thus frustrating any progress towards affordability. Second, while the rent laws have restricted speculators' ability to profit from tremendous rent gaps in rent stabilized housing, other new policies are recommodifying some formerly non-commodified housing forms. Finally, there has been no meaningful move toward democratising the planning process, thus retaining power among political and economic elites.

Housing affordability in New York City therefore remains in a contradictory state. The pace of rent increases has slowed, new non-profit housing development has increased, and, due to a glut of construction and international macro-economic shifts, the market for ultra-luxury condominiums in the city is weakening. At the same time, however, homelessness has grown to historical heights, rent burdens remain punishing for low-income residents, new construction favours the wealthy over those underserved by the current housing options, and public housing developments continue to deteriorate. In short, despite positive shifts, the city's affordability crisis is deepening. This parallel motion can be understood as a demonstration of the limits to municipal action - particularly in cities like New York with high land and construction costs - at a time when the federal government has long been not only absent from but hostile to efforts to increase urban affordability and integration (Schwartz, 2020). It also reflects the contradictory impulses of planning and development policy in New York City and State: even as both jurisdictions made important non-neoliberal housing policy interventions, both continued to be highly responsive to the city's real estate lobby, and have thus pursued tax, land use, and redevelopment programs that are generally favourable to real estate capital, such as ongoing tax incentives for luxury construction and conversion, rezonings to allow for more intensive high-end construction in working-class areas, and the transfer of public facilities to private development projects.

Similarly, while the state's strengthened rent controls have partially decommodified half of the city's private rental stock by significantly curbing opportunities to speculate, the city's public housing plan has made more than half of the city's public housing stock vulnerable to new forms of commodification. In the decade preceding the 2019 rent laws, New York City's rent stabilized housing stock was subject to repeated buy-outs by predatory equity firms that sought to buy such developments relatively cheaply, evict as many tenants as possible, strategically renovate the apartments, and sell them for tremendous profits (Fields, 2015). Now such owners will have a difficult time following through with their plans and are thus in the position of owning housing that, while still a valuable commodity, will not generate their predicted rents or command their desired sales price. Meanwhile, the city's embrace of RAD conversion has, in the name of saving public housing, created opportunities to 
transform this housing stock into a similar class of regulated commodity. The new managers, which range from non-profit Community Development Corporations to for-profit housing developers and are financed by some of the country's largest commercial banks, will not be able to treat public housing as a pure financial asset, as many restrictions and tenant protections are included in their public leases. Nevertheless, these managers will still be able to use the housing not only as a source of rental revenue but a means to access credit and a source of valuable tax exemptions (Hanlon, 2017). The state's most significant move toward decommodification, then, has been paired with one of the most significant commodifications of public housing in the city's history.

Finally, any trend toward democratizing the housing and planning system has come from below, with grassroots groups disrupting the established processes but policymakers yielding little in terms of procedural reform. This tension has been most visible in the city's zoning program. Despite persistent resistance, the city has pursued its plans with only minor modifications. The results have been mixed: in some cases, the rezonings have passed despite local opposition; in other cases, oppositional organizing has halted or reversed regressive rezonings. In several working-class areas under discussion for rezonings or major redevelopment projects, including Chinatown, Inwood, and Bushwick, tenant and community-based organizations created alternative plans for their neighbourhoods that included commitments to preserving and developing affordable housing. In each of these cases, however, the city has rejected their plans as simultaneously too ambitious and insufficiently growth oriented. In 2019, when the city's Charter was up for revision and renewal, both the Mayor and the City Council ignored calls from community coalitions to mandate a form of comprehensive planning instead of the divisive neighbourhood-by-neighbourhood zoning approach long practiced by New York City planners. These proposals were similarly rejected as political unfeasible and hostile to intensive real estate development (Khurshid, 2020).

While it is clear that some important aspects of New York City's neoliberal housing policy regime have been challenged, the city has not yet cohered into a meaningfully post-neoliberal formation that can pursue a path of affordability, decommodification, and democratisation.

\section{Berlin}

Berlin's neoliberal housing policy landscape

In 2018 , out of $1,950,000$ total housing units, Berlin's rental sector accounted for more than $1,600,000$ units or $85 \%$ of the total housing stock, with $71 \%$ privately owned, $19 \%$ municipally owned, and $12 \%$ collectively owned. Spread across those three segments, the rent regulated housing stock ${ }^{7}$ accounts for $13 \%$ of the system (with a total of 100,000 social housing units in former West-Berlin and 90,000 units with other forms of rent and occupancy-regulation in former East-Berlin) (IBB, 2019: 4749).

Housing policy in Germany takes place at all political scales. Private rental law as well as certain subsidies, planning, and building regulations are situated at the federal level. The federal states decide

\footnotetext{
${ }^{7}$ In everyday German language, different forms of subsidized (and therefore rent controlled) housing are subsumed under the term "Sozialwohnungen“ (social housing), but legally only a specific form of subsidy is called social housing (Sozialer Wohnungsbau). Therefore the term "rent regulated housing" is used here as a translation of the more universal German term "mietpreis- und belegungsgebunden“ (regulated in terms of rent level and unit allocation).
} 
partially on the allocation and criteria for the distribution of housing subsidies. Urban planning procedures and instruments are located at the municipal level. Berlin is a federal state, giving it more rights than other cities in Germany. Its 12 districts mostly function as municipalities.

Since the turn of the century, Berlin's reputation has shifted from that of a city of low rents and free spaces to the city with the most severe rent hikes in Germany. From 2011 to 2018, average asking rents increased $65 \%$ to $10,70 € /$ sqm (IBB 2019: 61), and there is a deficit of 220,000 units affordable to households earning less than $60 \%$ of the German median income (Holm et al., 2018: 70), making access to decent housing for low-income groups and - due to racist practices of landlords (e.g. Auspurg et al. 2017) - certain ethnic groups particularly difficult. It is those groups that are now leading a new tenant movement (Hamann and Vollmer, 2019).

The roots of this system lie in a deep neoliberal restructuring of Germany's and Berlin's housing politics beginning in the 1970 s. At the national level, subsidies for social housing have been cut, the Housing For the Common Good Law regulating the non-profit sector was abolished, and public (East Germany) and municipal (West Germany) housing was privatized (Schönig and Vollmer, 2018). In Berlin that lead to a decrease in municipal housing from 28\% of the total housing stock in 1990 to $18 \%$ in 2016 (Holm, 2008), and a decrease of social housing units from 20\% in 1995 to 5\% in 2018 (IBB 2006: 23; 2019: 48). Municipal housing was additionally used to subsidize the city's budget, leading to rent increases. The municipal housing companies' internal organization and administration was restructured according to private business models (Lederer and Naumann 2011). The city privatized most of its public land and restructured and reduced its administration according to new public management ideals (Silomon-Pflug, 2018). Austerity urbanism was accompanied by market- and state-led gentrification processes, rendering inner-city neighborhoods unaffordable for low-income inhabitants (Holm, 2013a). Financialized housing market actors entered Berlin's housing market with the privatsation of municipal housing and the liberalisation of Germany's financial markets in the early 2000s (Fields and Uffer 2016). All these developments left the city in a vulnerable position when it began to grow after a phase of shrinkage in 2008 (IBB, 2019: 14). This period of growth coincided with global "vagabond" (Katz, 2001) capital's search for new investment opportunities after the financial crisis.

The first actor to address the resulting crisis was a newly formed tenant movement, which, in the early 2010s, took action while political parties still denied the severity of the situation (Vollmer, $2019,2020)$. The forceful tenant movement and the extraordinary dynamic of the crisis eventually pressured parties and other institutional political actors to put the housing question back on the political agenda. The Social-Democratic and Conservative government coalition until 2016 and the SocialDemocratic, Left, and Green coalition from 2017 until 2021 introduced a number of housing policy reforms aimed at addressing the crisis.

\section{Housing policy responses}

In the municipal segment of the housing market, Berlin's Senate has started to depart from neoliberal housing strategies: privatisation is not allowed under the current legislature period; the municipal housing stock should be expanded from 270,000 to 360,000 units by 2021; and public land will be made available for new municipal housing (SenStadt/SenFin/LWU 2012, AGB, 2015, LWU, 2017). Furthermore, various measures to ensure the affordability of municipal housing were implemented. Annual rent increases are limited to $2 \%$. In addition, tenants paying more than $30 \%$ of their income can 
reduce their rent. $60 \%$ of available apartments are now reserved to households eligible for rent controlled housing.

Social and rent controlled housing in Germany was always conceptualized as a "social interim use" (Donner, 2000: 200): constructed by public, collective, and private companies alike, the housing units were designed to exit rent control after paying back subsidies. To counter the resulting loss, Berlin's government decided in 2014 to reintroduce subsidies for newly built rent-controlled housing. However, the aim of constructing 3,000 units per year will at best stabilize the current insufficient level (IBB, 2019: 48). The subsidies have also been diversified so that middle-class households with an income of up to $160 \%$ above the limit are now eligible. While a dispute over reforms to the existing social housing stock drags on, rent subsidies are being granted in social housing, thus reducing the rent for recipients to $30 \%$ of household income.

In order to dampen the rental price dynamics in the private housing sector, the State of Berlin and its districts had made use of several planning law instruments. For example, the state has introduced ordinances prohibiting the misappropriation of housing units or conversions of rental apartments into condominiums in certain areas of social conservation. In these same areas the city uses its right of first refusal to buy properties at market rates (Sarnow, 2019). All of these measures, however, are small steps and cover only parts of the private rental market. For years Berlin's tenant movement has called for a general rent freeze, but the city has always declared that it does not have jurisdiction to do so. After a campaign to expropriate big financialized landlords started in 2019 (see below), however, the government found a way to introduce a far-reaching measure: the so-called "rent cap". The law imposes a five-year moratorium on rent increases in most segments of the housing market - ironically excepting social housing, as well as buildings constructed after 2014 and after modernisation of apartments. The law also reduces rents if they exceed a fixed limit by more than $20 \%$ (AGB, 2020). Should landlords not obey, they can be fined up to 500,000€. The two main oppositional parties, the conservatives and the liberals, have filed constitutional suits against the law.

In terms of land policy, Berlin no longer privatizes its public land, but allocates possible sites of new construction according to social and other criteria, mostly to municipal housing companies. The city has returned to an active land policy of acquiring new plots (SenFin, 2020). The instrument of "Erbbaurecht", leasing of public land over a long time period to non-profit housing providers, is used to keep land in state ownership, reducing land costs for housing providers and thereby limiting unit costs. It also allows for far-reaching social regulations in leases (Runder Tisch Liegenschaftspolitik, 2018).

These policy reforms have been accompanied by attempts to restructure governance processes. This can be observed on the level of institutions and participation procedures.

In an attempt to convert the city's neoliberalised municipal housing companies into vehicles for social housing politics, the housing movement initiated a referendum proposing that the city's six limited liability or stock companies be consolidated into one public entity (Diesselhorst 2018). After the first step of the referendum passed, a compromise was negotiated and in 2016 the government introduced a public entity that oversees the six housing companies and their adherence to social cooperation agreements instead. Additionally, in reaction to the referendum, the city government introduced tenant councils that are elected in each company and vote on the companies' boards. 
The new Social Democrat, Left and Green government's coalition agreement of 2016 also promised stronger and better citizen participation in planning processes, for which new guidelines were drafted in a two year process, together with citizens randomly chosen from a pool of applicants (SenStadt 2019). Representatives of the tenants' movement were able to influence decision-making processes selectively through informal and formal means. For example, various groups and individuals were involved during in preparing the 2016 coalition agreement. In the district of FriedrichshainKreuzberg, a new association was established to support tenant initiatives, funded by the district. ${ }^{8}$

\section{Post-neoliberal Berlin?}

Do these new approaches constitute a post-neoliberal paradigm shift? In order to answer this question, the policies will be examined below according to the criteria of affordability, decommodification, and democratisation.

The rent cap introduced in early 2020 could substantially increase housing affordability for a large share of Berliners. However, the results or limitations of its implementation remain to be seen. It is unlikely that landlords will voluntarily adhere to the law. ${ }^{9}$ Tenants will have to report and enforce rent decreases individually. Tenant unions and a legal-tech startup are already campaigning to increase tenants' knowledge, but the individualized nature of rental law does not allow for collective overcharge lawsuits. Similar issues arise from the attempt to increase affordability in municipal and social housing by introducing a rent burden cap: initial studies show that tenants hardly applied for it, due perhaps to complicated procedures and lack of information (WVB, 2019: 17-20). In newly constructed municipal housing projects, $50 \%$ of units are supposed to be rent controlled. Given that almost half of Berlin's households are eligible (IBB, 2019: 32) and cannot find affordable housing on the private market, this allocation still cannot meet the demand. Nonetheless, a paradigm shift can indeed be observed in the realm of affordability: instead of fostering gentrification, measures have been taken to increase affordability for lower- and middle-income groups. Whether they are effective, however, remains to be seen.

In terms of decommodification, the city is attempting to increase its municipal housing stock through new construction and acquisition. Since 2016 the municipal housing companies have constructed 12,024 units and acquired 17,050 units, increasing the segment to 325,000 units in 2019. ${ }^{10}$ The practice of subsidizing the city's budget through revenue from the municipal housing companies has been abolished. However, the municipal stock remains far below 1990 levels. Greater levels of new construction are hampered by a lack of affordable and available land, layoff-induced capacity shortfalls in the housing companies and administrations, and shortages and high costs in the building industries. Acquisitions are expensive due to high market rates. These shortcomings pushed the tenant movement to adopt the campaign, "Deutsche Wohnen \& Co enteignen" ("expropriate Deutsche Wohnen and others") to socialize housing owned by financialized housing corporations that own more than 3,000 units. The campaign initiated a referendum in 2019 and took the first step successfully, collecting over 77,000 signatures in four months. The demands of the campaign are officially backed by the Left and

\footnotetext{
${ }^{8}$ The "Arbeits- und Koordinierungsstruktur für gemeinwohlorientierte Stadtentwicklung" (association to support urban development for the common good) is steered by a board of representatives from both the tenant movement and the district.

${ }^{9}$ As experiences with a rental law on the federal level - the Mietpreisbremse (rental break) - have shown, see Miettest e.V. (2017).

${ }^{10}$ Own calculations, based on numbers from WVB 2019 and SenStadt 2020.
} 
Green parties, while the Social Democrats decided against it after internal quarrels. Overall, attempts to partly decommodify the housing market have been made, but the local state lacks the resources to act on a grand scale because of past privatisation, out-sourcing, and restructuring, and because of legal constraints introduced on other political scales like debt limits and EU-competition laws forbidding the city from privileging public or local companies.

Neoliberalism's persistence is especially apparent in the realm of democratisation. The example of the municipal housing companies, which resist new social regulations and attempts toward internal democratisation whenever they can, illustrate the difficulties of democratizing deeply neoliberalised institutions (Bündnis "kommunal \& selbstverwaltet Wohnen", 2020). While some of the political personnel changed in the last government, the staff in the administrative bodies mostly remained. Long practiced market-oriented logics are not easily reversed, even when the political will to do so exists. The inclusion of citizens in decisions, especially if they act as organized civil society from the tenant movement, is still met with skepticism. Overall, meaningful democratisation - like including tenant representatives into decision making processes and institutions - is only reluctantly implemented (if at all) and must overcome many obstacles.

Berlin has turned away from further deepening neoliberal policies and, in some instances, has taken radical measures towards post-neoliberal housing policies. In other instances, however, neoliberal practices are carried on because of the persistence of neoliberal institutional restructuring and established actions and rationales.

\section{Vienna}

Vienna's neoliberal housing policy landscape?

Vienna's housing market shows stronger signs of decommodification than New York or Berlin. More than one-fifth of the city's housing units are municipally-owned and administered social housing (23\%) with below-market rents (from now on referred to as council housing), and another fifth (21.2\%) are rental units owned by non-profit housing associations. Though the latter require hefty down payments, rents in this segment are also significantly lower than in the private rental market. About one third (33\%) of the city's units are in the private rental sector, which is partly rent-controlled (Statistik Austria, 2019), and a final fifth of the city's housing stock is owner-occupied (19\%).

Housing policies in Vienna are embedded in a multi-scalar structure. The federal level, most importantly, regulates the Tenancy Act (particularly relevant for the private rental market), the NonProfit Housing Act, and the Homeownership Act. Moreover, taxes for housing subsidies, until recent decentralisation, were set and collected at the federal level before being redistributed to provinces such as Vienna. The local level, meanwhile, decides the specific uses of housing subsidies, administers council housing and parts of the non-profit stock, and sets the building codes that regulate zoning decisions.

Since the 1990s, Vienna's housing market has undergone a partial neoliberalisation. At the federal level, the Tenancy Act has been liberalised in favour of landlord interests. This includes more flexible rent setting rules and the introduction of temporary rental contracts, which have contributed to a comprehensive increase in the cost of private renting (Kadi, 2015). Decision-making power has been decentralised, while federal funding streams were reduced and made more flexible, thus increasing the role of private finance in housing provision (Deutsch, 2009). Right-to-buy options were introduced in the 
non-profit housing sector (Ball, 2005: 26), allowing tenants to purchase their flats after ten years (more recently changed to five years) and up until 20 years, resulting in a loss of units within this sector (GBV, 2016: 28).

At the local level, Vienna stopped building new council housing in 2004. Apart from attic conversions in existing buildings, the city-owned social housing stock, which is on average the cheapest sector on the market, has not been expanded (except some recent initiatives, see below). Although the city has continued to promote non-market housing provision through non-profit providers, the downpayments demanded in this sector often constitute a financial access barrier, despite available subsidies from the city. With regard to housing costs and accessibility, the social rental sector has thus come closer to resembling the private market (Kadi, 2015). Meanwhile, housing subsidies were opened to commercial developers, rather than just being granted to non-profit providers - a longer-term shift that originated in the 1970s (Matznetter, 1990: 195). In contrast to non-profit providers, rents in subsidized units built by commercial providers are usually only temporarily regulated, limiting the long-term contribution of this sector to the affordable housing stock.

Compared to New York and Berlin, the extent of neoliberalisation in Viennese housing policy remains limited. The city has not, for example, pursued a comprehensive privatisation of its municipal housing stock. The city also continued to invest in the provision of non-profit housing on a relatively steady basis. Nonetheless, in the context of market-based reforms, housing problems in the city have become more pressing and rents have risen significantly faster than incomes, specifically since the mid2000s. Affordability burdens have thus increased (Statistik Austria, 2019), particularly for low-income households and those newly moving to the city (Kadi, 2015). People from ethnic minorities are often severely affected, reflecting, not least, long-standing discrimination by private landlords and the social housing system (Aigner, 2018: 799).

\section{Housing policy responses}

In response to rising housing problems and broader public debate, the city has implemented a new set of housing reforms. In 2015, Vienna restarted council housing construction, with 4,000 new units planned until 2025. The rents are set at $€ 7.50$ per $\mathrm{m} 2^{11}$ and no down-payments are required from tenants. The first project, with 120 residential units, was completed in fall, 2019 (Wiener Wohnen, 2019). In addition, new subsidy programmes for non-profit housing were introduced. The "Smart Homes" program, for example, promotes apartments with small floor plans and low costs. Tenant downpayments are limited to $60 € / \mathrm{m} 2$, which is considerably lower than the city-wide average (around $500 / \mathrm{m} 2$ according to Korab et al. 2009). Half of the apartments are allocated through the city with the same access criteria as for council housing, and the rest are allocated directly through housing providers. Plans currently call for the construction of 2,000 to 3,000 "Smart Homes" per year. Recently, the city announced that $50 \%$ of all subsidized apartments will be part of this program in the future (Stadt Wien, 2019).

Another new measure is the "Housing Initiative", which provides low-cost loans to housing providers. Down-payments from tenants are limited but can be up to $500 € / \mathrm{m} 2$. Rent control for these units, however, is only temporary. If the property developer is a commercial provider, the rent can be raised to market levels after ten years when the property is re-let (City of Vienna, 2020). However, the

\footnotetext{
${ }^{11}$ Including taxes, excluding heating.
} 
first contract that the housing provider grants needs to be time-unlimited and tenants have security of tenure. As with Smart Homes, half of the apartments are allocated by the city, and half are allocated through the housing providers. In contrast to other funding schemes, there are no upper income limits for tenants (Wohnberatung Wien, 2019).

While new measures were taken in the council housing and non-profit housing sectors, much less has happened in the private rental sector, where the effects of neoliberal reforms have become particularly visible. Alongside more flexible rent setting rules and the possibility of temporary rental contracts, the deregulation of the Tenancy Act enabled landlords to seek higher rents in areas with higher land prices. ${ }^{12}$ In the past such a location bonus was not possible, as rents had to be set only according to the equipment standard of the unit (with units holding the highest equipment standard exempted from regulation). Since the financial crisis of 2008, new investors have entered the sector and taken the opportunity to increase rents (Kadi and Verlic, 2019). Inexpensive units in the sector are also disappearing due to their conversion into permanent holiday homes (e.g. Airbnb) (Seidl, Plank and Kadi, 2017).

Land and planning policies have seen more sweeping reforms. The city has reformed the local zoning code and introduced the category "subsidized housing" to make more land available for such development. According to the housing subsidy regulations, land costs for subsidized housing must not exceed $€ 188 / \mathrm{m} 2$ realized living space. However, land below this limit has become increasingly scarce. In disinvested areas, the average was around $€ 600$ per $\mathrm{m} 2$ realized living space, while in invested areas it was up to 2,000€ (Ritt, 2015: 42). The reformed building code stipulates that greenfield properties which are zoned for construction or properties on which the permitted building height is increased above a certain level must predominantly be dedicated as "subsidised housing". "Predominantly" is defined as $2 / 3$ of the land. On properties dedicated to "subsidised housing", rents are regulated $(\sim 5 € / \mathrm{m} 2)$, apartments cannot be resold for 40 years (the city holds a pre-emptive right-to-buy), and land sale prices may not exceed the maximum sum for land costs that is established in the housing subsidy regulation. This regulation applies to all properties where a developer plans to build more than 5,000 $\mathrm{m} 2$ of residential space.

Hardly any significant changes have taken place at the level of governance. Vienna's housing policy is traditionally strongly institutionalised and characterized by a high degree of stability and consensus politics that encompasses different interest groups. This corporatist system has not been substantially restructured through neoliberal reforms in the past. It is, however, not conducive to democratic decision-making and bottom-up participation.

\section{Post-neoliberal Vienna?}

Do these measures represent a post-neoliberal shift in terms of an expansion of affordability, decommodification, and democratisation? Affordability will be improved through restarting the council housing program and implementing the new subsidy programs. There are, however, important limitations to consider. The subsidy programs come with qualitative restrictions. The "Smart Homes" program, for example, explicitly provides units with low costs, but small and "efficient" floor plans. While expanding the inexpensive housing pool, the programs seem to prioritize affordability at the

\footnotetext{
12 Legally, landlords are bound to ask $25 \%$ lower rents in temporary rental contracts. In practice, this is, however, often disregarded (Rosifka \& Postler, 2010). Tenants can have their rent checked at the municipality.
} 
expense of other criteria of housing quality. There are also restrictions in terms of accessibility. The reforms redefined entry requirements for council housing, and while the range of social groups that have access to this housing has widened (because upper-income limits have been raised), access for newcomers to the city has become more difficult. People who have been living in Vienna for longer are given priority in the allocation of housing and can move up the waiting lists by up to one year, thus discriminating in particular against immigrants.

The expansion of affordable housing also needs to be contrasted with the lack of political engagement with the private rental sector. Despite rapid market intensification, no regulatory steps were taken to restrict these rents. While affordable housing is thus added to the council housing and the non-profit stock, it is diminished through the loss of inexpensive private rental units. The main reason for this deficiency is a lack of local legal authority. The Tenancy Act is in the hands of the federal government, which, particularly under the recent conservative and right-wing party coalition, has shown no interest in tighter regulation, and instead signalled stronger alignment with the real estate lobby. Meanwhile, the land policy reform provides a potentially highly effective tool for expanding affordable housing in the coming years, but its effectiveness remains to be seen. Taken together, affordable housing is thus expanded, but there are important restrictions in terms of the quality and the accessibility of the new housing programs. The lack of reforms in the private rental sector diminishes the affordable housing stock, while land policies promise a considerable expansion in the near future.

Concerning decommodification, the restart of the council housing program and the introduction of new subsidy programs for the non-profit sector have expanded the non-market housing stock. This is not the case for the 'Housing Initiative' programme, which promotes commercial property developments under temporary rent controls. However, the currently low capital market interest rates will reduce the attractiveness of that program to commercial developers. Decommodification will also be indirectly but substantially promoted through the land policy reforms, which will de facto reserve two-thirds of land in new developments for subsidized housing. For council housing and the subsidy programs, however, the scope of the measures is critical. According to current forecasts, the population of Vienna will grow by more than 150,000 people by 2030 . In this light, the planned expansion of council housing by 4,000 units by 2025 is a drop in the ocean. With an average construction of around 10,000 units annually in the city overall, this is not even enough to keep the share of council housing in the housing stock (currently 23\%) constant, let alone expand it. Meanwhile, in recent years a significant portion of new construction has shifted from subsidized units towards commercially financed units, producing housing that is unaffordable for most low-income households. It remains to be seen whether the subsidized, non-profit sector will regain ground in the coming years.

These selective reforms contrast starkly with the lack of change in governance towards greater democratisation. The highly institutionalised housing policy system in Vienna has not seen far-reaching reforms, and there have been no major shifts towards more democratic decision-making in housing policy, planning procedures, and relevant institutions. The housing council and municipal departments for housing and finance remain central to the practical implementation of housing policy. Major changes in these areas did not occur with the changing government in 2010 in terms of administrative decisionmaking (the Social Democrats have been in coalition with the Greens since then, before entering a coalition with the liberal party in 2020). This is also the case for the democratisation of institutions and planning procedures, for which no major changes were implemented. 
Neoliberalism has only partially taken hold in Vienna's policy landscape, but market-based reforms have nonetheless affected the housing system. The recently implemented reforms constitute a selective correction to these measures. They signal steps away from market-based principles and as a result will foster affordability and decommodification. Some of these reforms are limited in scope and relevance (e.g. the 'Housing Initiative'), while others entail quite far-reaching elements (e.g. land policy). Important elements of the pre-existing market-based policy landscape remain unchanged, however, as a result of the local government's lack of authority to address relevant legal matters.

As a partially neoliberalised city, Vienna has taken several steps towards post-neoliberalism. These reforms, however, do not yet constitute a full-fledged post-neoliberal shift in terms of a significant, combined expansion of decommodification, affordability and democratisation.

\section{Conclusion}

The neoliberalisation of housing policy since the 1970s has been characterized by three intertwined features: measures to render housing unaffordable for lower-income groups; commodification of formerly decommodified sectors of the housing market; and institutional restructuring processes that give greater power to real estate actors than tenants in governance, planning, and housing provision. Consequently, post-neoliberal housing policies would be characterized by significant shifts away from these three modes towards deeper affordability, decommodification, and democratisation. By focusing empirically on three cities that are comparably more interventionist than other cities in their respective countries, but are embedded in contrasting housing policy contexts that range from liberal and highly neoliberalized (New York) to fairly regulated and moderately neoliberalized (Vienna), our analysis reveals that all three cases have implemented policy measures in response to rising housing hardships and protests. These reforms represent steps towards greater affordability and dampening hyper-commodification. In all three cases, however, we find that little has been done to democratise the housing and planning systems. In each city, the previous modes of highly institutionalized, top-down, and often real estate industry driven planning and policymaking systems and practices have largely been sustained despite other, sometimes significant changes to the housing system. Ultimately, while important changes have been implemented in New York, Berlin, and Vienna, no coherently post-neoliberal housing policy regime that encompasses changes in all three domains has yet emerged.

While our analysis cannot account for all of the nuances in the specific policy forms or magnitudes of reform across cases, it adds a more international perspective focused on cities in highly diverse housing systems and introduces an analytical framework to the debate - both of which have been largely lacking in the literature on post-neoliberal housing policy. Our findings support the claim that relevant reforms have been implemented beyond the contexts studied so far, but also underline the value of a differentiated framework to assess the departure from neoliberal housing policies. While the analysis thus contributes empirically and conceptually to our understanding of local (post)neoliberal housing policy trajectories, our framework invites further systematic examinations of cases in other welfare and housing system contexts to determine commonalities and differences with the cities examined here. 
By way of conclusion, we discuss some structural factors that impede a genuinely postneoliberal transformation in our cases - besides a simple lack of political will on the part of some actors. We focus on four factors that we consider to be particularly important. They are not external to neoliberalism, but rather are integral features of the neoliberal order that secure its endurance. They are not set in stone, but to change or remove them would require additional and substantial political organizing and mobilization on the part of housing and other social movements. We illustrate with selective examples.

A first set of factors are neoliberal discourses and ways of governing that are deeply inscribed into local policy practices and institutional fabrics. In all three cities, such continuities shape policymaking. In New York, affordable housing production has long been tied to the production of luxury housing, and this modus operandi has remained in place through the Mandatory Inclusionary Housing policy and the proliferation of public-private partnership projects (Stein, 2019: 126-132). In Berlin, neoliberal operational continuity operates at the level of municipal housing companies. Although $100 \%$ publicly owned, they function as private entities which impede parliamentary and administrative control. Restructuring the companies into public entities is not a feasible option since EU regulations would restrict them from taking on debt and complicate their operations. EU regulations thus impede decommodification in Berlin. In Vienna, the significant support of the private sector in providing temporarily affordable housing may be recent, but it has become inscribed in the local policy regime and continues to be pursued rather uncritically as a viable funding strategy.

A second factor is the influence of the real estate industry and the financial sector, which is exerted through lobbying and ties to the ruling parties - or, in corporatist arrangements, through direct cooperation with state institutions. Real estate accounts for a crucial contributor to both municipal budgets and campaign finance, and has been both formally and informally incorporated into planning politics. In New York, the Economic Development Corporation, which is responsible for major private redevelopment projects on public land, has a board of directors comprised of half mayoral appointees and half appointees of the Partnership for New York, a private business lobbying organisation. With a real estate developer serving as the president of the United States from 2016 to 2020, these dynamics are even more entrenched at the federal level. In Berlin, the real estate industry has developed longlasting ties with the local government -- and the Social Democratic party in particular -- to form what Holm (2013b: 44) calls a "real estate valorization coalition". In Germany more generally, private property owners have a strong say in planning decisions and the planning process to promote their interests. In Vienna, lobbying influence is particularly visible at the federal level, where private landlords and property owners successfully pressured the government to weaken rent regulation in the early 1990s and, more recently, pushed the last government to take up most of their demands in the coalition agreement - some even word-for-word (Kadi, 2018).

A third factor is scalar authority, itself an outcome of political decisions and struggles. Many dimensions of housing policy are controlled and decided at higher levels of government than the municipality. In the United States, the federal government in the 1970 s placed a moratorium on new public housing construction, and in the 1990s Congress legislated that the federal government would not pay for any net increase in a local public housing authority's stock, severely restricting cities like New York from expanding their public housing programs. Meanwhile, control over rent regulation and taxation is held at the state level, thus preempting New York City from expanding such programs independently. In Germany relevant legislative authority, such as the regulatory power to reinstall a 
non-profit housing law or regulations of private rental law, are held at the federal government. The recent struggle over the rent cap, however, shows that a supposed lack of legislative authority can sometimes also cover for a lack of political will to overcome such barriers. In Vienna, the lack of municipal power is particularly acute for rent regulation. While the city has enacted several changes to the local planning code to counter federal deregulation (e.g. related to Airbnb or building demolition), they have not been enough to halt the private rental market's comprehensive restructuring. The real estate industry has lobbied successfully at the federal level to prevent any substantial reregulation for the time being. Furthermore, for Berlin and Vienna, EU rules restrict municipalities' room to maneuver in providing non-market housing, particularly in relation to limitations on municipal debt.

A fourth and final factor relates to macroeconomic dynamics and global capital flows. In the US and Europe, interest rates remain at historic lows, while quantitative easing and institutional investors (such as financial-market based retirement and security funds) have pushed historic quantities of capital into real estate in search of competitive returns (Aalbers, 2015). This dynamic has reshaped many local housing markets and put pressure on the affordable housing supply. In New York City, developers were, until recently, building massive skyscrapers full of luxury condominiums which were pitched to buyers more as investments than as dwellings. Meanwhile, US-based and international real estate investment companies have capitalized on rent gaps in the private rental sector - including rent regulated and subsidized housing - to extract profits by gentrifying neighborhoods (Fields and Uffer, 2016). Likewise, in Berlin the local housing market has become a haven for global real estate capital in the post-2008 context. Growing investments have been central to the restructuring of the city's rental market, with institutional investors in particular gaining relevance (Fields and Uffer, 2016). Vienna's housing market continues to be dominated by small-scale, local landlords, but large-scale purchases in the private rental stock have gained ground in a market that is still considered relatively inexpensive and thus offering the potential for attractive returns. Meanwhile, in the context of low-interest rates, household investment in property has become an increasingly significant savings method among middle and upper-class households, pushing up prices and rents in all three cities.

These factors currently work to maintain the neoliberal order and impede the emergence of genuinely post-neoliberal housing policy regimes in New York City, Berlin, and Vienna. If housing movements grow further and their demands continue to escalate, however, local, regional, and national governments will be forced to address these structural arrangements and "ways of doing things" in order to maintain legitimacy and provide for the basic needs of shelter and home.

\section{References}

Aalbers MB (2013) Debate on Neoliberalism in and after the Neoliberal Crisis. International Journal of Urban and Regional Research 37(3): 1053-1057.

Aalbers MB (2015) The Great Moderation, the Great Excess and the global housing crisis, International Journal of Housing Policy, 15(1): 43-60.

AGB - Abgeordnetenhaus Berlin (2015) Gesetz über die Neuausrichtung der sozialen Wohnraumversorgung in Berlin. Berliner Wohnraumversorgungsgesetz. WoVG BIn. Available at: 
https://www.stadtentwicklung.berlin.de/wohnen/wohnraumversorgung/download/VorlageBesch lussfassung_WoVG_Bln.pdf

AGB - Abgeordnetenhaus Berlin (2020) Mietenbegrenzung im Wohnungswesen in Berlin. MietenWoG Bln. Available at: https://www.berlin.de/sen/justiz/service/gesetze-und-verordnungen/2020/ausgabenr-6-vom-22-2-2020-s-49-56.pdf

Aigner A (2018) Housing entry pathways of refugees in Vienna, a city of social housing. Housing Studies 34(5): 779-803.

Angotti T and Morse S (2017) Zoned out! Race, displacement, and city planning in New York City. New York: Urban Research.

Auspurg K, Hinz T and Schmid L (2017) Contexts and conditions of ethnic discrimination: Evidence from a field experiment in a German housing market. Journal of Housing Economics 35(3): 26-36.

Ball M (2005) RICS European Housing Review 2005. London: Royal Institution of Chartered Surveyors.

Barbanel J (2019) New York evictions are plunging under new rent control law. Wall Street Journal, 16 November.

Belina B and Schipper S (2009) Die neoliberale Stadt in der Krise? Z. Zeitschrift marxistische Erneuerung 80: 38-51.

Bourne L (1981) The Geography of Housing. London: Edward Arnold.

Brand U (2016) Postneoliberalism. In: S. Springer, K. Birch and J. MacLeavy, eds. The Handbook of Neoliberalism. London: Routledge, pp.583-591.

Brand U and M Sekler (2009). Postneoliberalism: Catch-All Word or Valuable Analytical and Political Concept? Aims of a Beginning Debate. Development Dialogue, 51: 5-13.

Braun MZ (2020) New York city property values rise 4.7\% on construction boom. Bloomberg News, 16 January.

Brenner N, Peck J and Theodore N (2010) After neoliberalization? Globalizations 7(3): 327-45.

Bündnis "kommunal \& selbstverwaltet Wohnen" (2020) Öffentliche Hand und alles gut? Mieter*innen für die Demokratisierung der öffentlichen Wohnraumversorgung. In: Schönig B and Vollmer L (eds.) Wohnungsfragen ohne Ende?! Ressourcen für eine soziale Wohnraumversorgung. Bielefeld: transcript.

Carr J (2012) Public input/elite privilege: The use of participatory planning to reinforce urban geographies of power in Seattle. Urban Geography, 33(3): 420-441.

City of Vienna (2020) Wohnbauinitiative 2015. Available at: https://www.wien.gv.at/wohnen/wohnbaufoerderung/wohnbauinitiative-2015.html (accessed 8 February 2021) 
Coalition for the Homeless (2019) Basic facts about homelessness: New York City. Available at :

https://www.coalitionforthehomeless.org/basic-facts-about-homelessness-new-york-city/ (accessed 5 February 2020).

Crouch C (2011) The Strange Non-Death of Neoliberalism. Cambridge: Polity Press.

Deutsch E (2009) The Austrian Social Rented Sector at the Crossroads for Housing Choice. European Journal of Housing Policy 9(3): 285-311.

Diesselhorst J (2018) Wenn stadtpolitische Bewegungen das Terrain des Staats betreten. Zwischen Berliner Mietenvolksentscheid und „Wohnraumversorgungsgesetz. Prokla. Zeitschrift für kritische Sozialwissenschaften 48(191): 265-282.

DiPrinzio H (2019) State finally releases $\$ 450$ million promised to NYCHA. City Limits, 8 November.

Donner C (2000) Wohnungspolitiken in der Europäischen Union. Theorie und Praxis. Wien: self-published.

Fields D (2015) Contesting the financialization of urban space: Community organizations and the struggle to preserve affordable rental housing in New York City. Journal of Urban Affairs, 37(2): 144-165.

Fields D and Uffer S (2016) The financialisation of rental housing. A comparative analysis of New York City and Berlin. Urban Studies 53(7): 1486-1502.

Gaumer E (2018) Selected initial findings of the 2017 New York City Housing and Vacancy Survey. New York: New York City Department of Housing Preservation and Development.

GBV (2016) Jahresstatistik [Annual statistics]. Vienna: self-published.

Goetz E (2013) New deal ruins: Race, economic justice, and public housing policy. NY: Cornell University Press.

Goldstein BD (2017) The roots of urban renaissance. Cambridge, MA: Harvard University Press.

Gurian C (2003) Let them rent cake: George Pataki, market ideology, and the attempt to dismantle rent regulation in New York. Fordham Urban Law Journal, 31(2): 339-411.

Hamann U and Vollmer L (2019) Mieter*innenproteste in der postmigrantischen Stadt. Forschungsjournal Soziale Bewegungen 32(3): 364-378.

Hanlon J (2017) The origins of the rental assistance demonstration program and the end of public housing. Housing Policy Debate 27(4): 611-639.

Harvey D (1989) From Managerialism to Entrepreneurialism: The Transformation in Urban Governance in Late Capitalism. Geografiska Annaler: Series B, Human Geography 71(1): 3-17.

Hay C (2004) Common trajectories, variable paces, divergent outcomes? Models of European capitalism under conditions of complex economic interdependence. Review of International Political Economy 11(2): 231-262.

Holm A (2008) Privatisierung des kommunalen Wohnungsbestandes. In: Gestring N, Glasauer H, Hannemann C, Petrowsky W and Pohlan J (eds.) Schwerpunkt: Arme reiche Stadt. Opladen Germany: Verlag Barbara Budrich, pp.101-109. 
Holm A (2013a) Berlin's Gentrification Mainstream. In: Bernt M, Grell B and Holm A (eds.) The Berlin reader. A compendium on urban change and activism. Bielefeld: transcript, pp.171-187.

Holm A (2013b) Wir bleiben Alle! Gentrifizierung-Städtische Konflikte um Aufwertung und Verdrängung. 2. Auflage. Münster: Unrast.

Holm A, Lebuhn H, Junker S and Neitzel, K (2018) Wie viele und welche Wohnungen fehlen in deutschen Großstädten? Die soziale Versorgungslücke nach Einkommen und Wohnungsgröße. Working paper Forschungsförderung Hans Böckler Stiftung.

Jacobs K (2019) Neoliberal housing policy: An international perspective. London, New York: Routledge.

IBB - Investitionsbank Berlin (2006) Wohnungsmarktbericht 2005. Berlin.

IBB - Investitionsbank Berlin (2019) Wohnungsmarktbericht 2018. Berlin.

IBB - Investitionsbank Berlin (2020) Wohnungsmarktbericht 2019. Berlin.

Kadi J (2015) Re-commodifying housing in formerly 'Red' Vienna? Housing, Theory and Society 32(3): 247265.

Kadi J (2018) Die Immobilienwirtschaft im Regierungsprogramm [The real estate lobby and the coalition agreement]. Blog Arbeit und Wirtschaft. Available at: https://www.awblog.at/dieimmobilienwirtschaft-im-regierungsprogramm./ (accessed 23 March 2020).

Kadi J (2020). Wohnen als Anlagegutprodukt [Housing as asset]. In: IBA_Wien 2022/future Lab (Eds.) Neues soziales Wohnen, Jovis: Hamburg: pp. 72-55.

Kadi J and Ronald R (2014) Market-based housing reforms and the 'right to the city': the variegated experiences of New York, Amsterdam and Tokyo. International Journal of Housing Policy 14(3): 268-292.

Kadi J and Ronald R (2016) Undermining housing affordability for New York's low-income households: The role of policy reform and rental sector restructuring. Critical Social Policy 36(2):265-288.

Kadi J and Verlic M (2019) Gentrifizierung am privaten Wiener Mietwohnungsmarkt. In: Kadi J and Verlic M (eds.) Gentrifizierung in Wien. Stadtpunkte Nr. 27. Wien: Arbeiterkammer Wien, pp. 35-46.

Katz C (2001) Vagabond capitalism and the necessity of social reproduction. Antipode 33(4): 709-728.

Kemeny J (1995) From public housing to the social market: rental policy strategies in comparative perspective. Routledge: London.

Khurshid S (2020) City Council pursues comprehensive planning legislation. Gotham Gazette, 3 February.

Korab R, Romm T and Schönfeld A (2010) Einfach Sozialer Wohnbau. Aktuelle Herausforderungen an den geförderten Wiener Wohnbau und Eckpfeiler eines Programms 'einfach sozialer Wohnbau'. Available at: https://www.wohnbauforschung.at/index.php?id=317

Lederer K and Naumann M (2011) Linke Metropolenpolitik und öffentliche Unternehmen. Eine Bestandsaufnahme am Beispiel Berlins. In: Holm A (ed.), Linke Metropolenpolitik. Erfahrungen und Perspektiven am Beispiel Berlin. Münster: Westfälisches Dampfboot: pp.128-144. 
LWU - Landeseigene Wohnungsunternehmen (2017) Offener Brief „Neubau Kooperationsvereinbarung ,Leistbare Mieten, Wohnungsneubau und soziale Wohnraumversorgung'vom 5. April 2017, Roadmap zum Neubau vom 12. April 2016". Berlin. Available at: https://www.tagesspiegel.de/downloads/20324282/1/brief lompscher.pdf (accessed 4 April 2020).

Macdonald L and Ruckert A (2009) Post-Neoliberalism in the Americas: An Introduction, in Macdonald L. Ruckert A. , eds. Post-Neoliberalism in the Americas: Beyond the Washington Consensus? London: Routledge: 1-20.

Marwell NP and Mclnerney PB (2005) The nonprofit/for-profit continuum: Theorizing the dynamics of mixed-form markets. Nonprofit and Voluntary Sector Quarterly, 34(1): 7-28.

Matznetter W (1990) What kind of privatization? Neth. J. of Housing and Environmental Res., 5(2): 181197.

Matznetter W (2002) Social Housing Policy in a Conservative Welfare State: Austria as an Example. Urban Studies 39(2): 265-282.

Miettest e.V. (2017) Finanzielle Lasten für Mieter durch Überschreitung der Mietpreisbremse. Analyse von Wiedervermietungen in Berlin, Hamburg und Stuttgart. Studie im Auftrag der Bundestagsfraktion Bündnis 90/die Grünen. Available at: www.derparitaetische.de/index.php?id=450\&rid=t_127\&mid=393\&aC=f4d3d94d\&jumpurl=0

Mironova O and Waters T (2020) How Social Is That Housing? Community Service Society, February 18, 2020. Available at: https://www.cssny.org/news/entry/how-social-is-that-housing (accessed 30 March 2020)

Mirowski P (2013) Never Let a Serious Crisis Go to Waste: How Neoliberalism Survived the Financial Meltdown. London: Verso.

Moody K (2007) From welfare state to real estate: Regime change in New York City, 1974 to the present. New York: New Press.

Mundt A and Amann W (2010) Indicators of an Integrated Rental Market in Austria. Housing Finance International 25(2): 35-44.

Newman K (2018) Urban governance and inclusionary housing in New York City. In: Davidson M and Ward K (eds.) Cities under austerity: Restructuring the US metropolis. Albany: SUNY Press, pp.127-142.

Parnell S and Robinson J (2012) (Re) theorizing cities from the Global South: Looking beyond neoliberalism. Urban Geography 33(4): 593-617.

Peck J, Theodore N and Brenner N (2010) Postneoliberalism and its Malcontents. Antipode, 41(1): 94-116.

Radford G (1996) Modern housing for America: Policy struggles in the New Deal era. Chicago: University of Chicago Press.

Rinn M (2018) Ein Urbanismus der Ungleichheit. ,Neue soziale Stadtpolitik' in Hamburg als Strategie der Verbürgerlichung. sublurban. zeitschrift für kritische stadtforschung 6(1): 9-28. 
Ritt T (2015) Gutes Wohnen in einer wachsenden Stadt. Stadtpunkte: Wien Wächst Wien Wohnt. Wien: Arbeiterkammer, pp. 27-45.

Rosifka W and R Postler (2010) Die Praxis des Richtwert-Mietzinssystems Ergebnisse einer Untersuchung über Mietvertragsabschlüsse in Wien [The Practice of Richtwert-Mietzinssystems. Results of an Evaluation of Rental Contracts in Vienna]. Wien: Arbeiterkammer Wien.

Rossi U and Vanolo A (2015) Urban neoliberalism. International encyclopedia of the social \& behavioral sciences: 846-853.

Runder Tisch Liegenschaftspolitik (2018) Erbbaurechte in Berlin. Dokumentation der Expertenwerkstatt. Berlin. Available at: https://www.exrotaprint.de/wpcontent/uploads/2018/01/Erbbaurechtswerkstatt Dokumentation.pdf (accessed 15 January 2021).

Sarnow M (2019) „Wir kaufen den Kiez zurück“. Milieuschutz und Vorkaufsrecht als Ansätze einer postneoliberalen Wohnraumversorgung in Berlin Friedrichshain-Kreuzberg? sublurban. zeitschrift für kritische stadtforschung 7(1/2): 115-136.

Schipper S (2015) Towards a 'Post-Neoliberal' Mode of Housing Regulation? The Israeli Social Protest of Summer 2011. International Journal of Urban and Regional Research 39(6): 1137-1154.

Schipper S (2018) Wohnraum dem Markt entziehen? Wohnungspolitik und städtische soziale Bewegungen in Frankfurt und Tel Aviv. Wiesbaden: Springer Fachmedien Wiesbaden.

Schönig B, Rink D, Gardemin D and Holm A (2016) Paradigmenwechsel in der kommunalen Wohnungspolitik? Variationen kommunalisierter Wohnungspolitik im transformierten Wohlfahrtsstaat. In: Barbehön M and Münch S (eds.), Variationen des Städtischen - Variationen lokaler Politik. Wiesbaden: Springer Fachmedien Wiesbaden, pp.25-62.

Schönig B and Vollmer L (2018) Wohnungsnot gestern und heute. Informationen zur Raumentwicklung 4: 6-19.

Schwartz A )2019) New York City's Affordable Housing Plans and the Limits of Local Initiative. Cityscape 21(3): 355-388.

Seidl R, Plank L and Kadi J (2017) Airbnb in Wien: eine Analyse. Interaktiver Forschungsbericht. Available at: https://wherebnb.in/wien (accessed 4 December 2020).

SenFin - Senatsverwaltung für Finanzen (2020) Senat betreibt aktive Grundstücksvorsorge: Aufbau strategischer Reserve für künftige Generationen. press release. Available at: https://www.berlin.de/rbmskzl/aktuelles/pressemitteilungen/2020/pressemitteilung.896360.ph p (accessed 4 April 2020).

SenStadt - Senatsverwaltung für Stadtentwicklung und Wohnen (2019) Leitlinien für Beteiligung von Bürgerinnen und Bürgern an Projekten und Prozessen der räumlichen Stadtentwicklung.

SenStadt - Senatsverwaltung für Stadtentwicklung und Wohnen (2020) Mietendeckel, Wohnungsneubau \& Projekte. press release. Available at: https://www.stadtentwicklung.berlin.de/aktuell/pressebox/archiv volltext.shtml?arch 2001/nac hricht6850.html (accessed 4 April 2020). 
SenStadt - Senatsverwaltung für Stadtentwicklung und Wohnen / SenFin - Senatsverwaltung für Finanzen / LWU - die landeseigenen Wohnungsunternehmen (2012) Bündnis für soziale Wohnungspolitik und bezahlbare Mieten. cooperation agreement.

Silomon-Pflug F (2018) Verwaltung der unternehmerischen Stadt. Zur neoliberalen Neuordnung von Liegenschaftspolitik und-verwaltung in Berlin und Frankfurt am Main. Bielefeld: transcript.

Smith N (1996) The New Urban Frontier: Gentrification and the Revanchist City. New York: Routledge.

Smith N (2008) Neo-liberalism. Focaal 2008/51: 155-157.

Springer S (2015). Postneoliberalism? Review of Radical Political Economics, 47(1): 5-17.

Stadt Wien (2019) Jede zweite geförderte Wohnung künftig SMART. Available at:

https://www.wien.gv.at/bauen-wohnen/smart.html (accessed 4 September 2019).

Statistik Austria (2019) Wohnen 2018. Zahlen, Daten und Indikatoren der Wohnstatistik. Statistik Austria: Wien.

Statistik Berlin Brandenburg (2020): Zeitreihe Bruttomonatsverdienste ohne Sonderzahlungen im Produzierenden Gewerbe und Dienstleistungsbereich in EUR. https://www.statistik-berlinbrandenburg.de/BasisZeitreiheGrafik/zeitVerdiensterhebung.asp?Ptyp=400\&Sageb=62003\&creg=BBB\&anzwer=6 (accessed 13 November 2020).

Stein S (2019) Capital city: Gentrification and the real estate state. London/New York: Verso Books.

Stein S (2018) Progress for whom, toward what? Progressive politics and New York City's mandatory inclusionary housing. Journal of Urban Affairs 40(6): 770-781.

Streeck W (2011) The crisis of democratic capitalism. New Left Review 71: 5-29.

US Census Bureau (2009) American Community Survey, 1-year estimate.

US Census Bureau (2019) American Community Survey, 1-year Estimate.

Vogelpohl A and Buchholz T (2017) Breaking With Neoliberalization by Restricting The Housing Market. Novel Urban Policies and the Case of Hamburg. International Journal of Urban and Regional Research 41(2): 266-281.

Vollmer L and Kadi J (2018) Wohnungspolitik in der Krise des Neoliberalismus in Berlin und Wien: Postneoliberaler Paradigmenwechsel oder punktuelle staatliche Beruhigungspolitik? PROKLA. Zeitschrift für Kritische Sozia/wissenschaft 48(191): 247-264.

Vollmer L (2019) Mieter_innenbewegungen in Berlin und New York. Die Formierung politischer Kollektivität. Wiesbaden: Springer.

Vollmer L (2020) Changing Political Collectivities in Times of Crisis: Tenant Protest in Berlin and New York. In: Turner BV, Wolf H, Fitzi G and Mackert J (eds.) Urban Change and Citizenship in times of crisis. Abingdon/New York: Routledge. 
Whitlow J (2019) Gentrification and countermovement: The right to counsel and New York City's affordable housing crisis. Fordham Urban Law Journal, 46(5): 1081-1136.

Wiener Wohnen (2019) Gemeindebau Neu. Available at: https://www.wienerwohnen.at/gemeindebauneu.html (accessed 4 September 2019).

Wohnberatung Wien (2019) Wiener Wohnbauinitiativen 2011 + 2015. Available at: https://www.wohnberatung-wien.at/wohnberatung/wohnbauinitiative/(accessed 4 September 2019).

WVB - Wohnraumversorgung Berlin AöR (2019) Bericht zur Kooperationsvereinbarung über das Jahr 2018. Berlin. 